\title{
Selected DHS data on 10-14-year-olds: Côte d'Ivoire
}

Population Council

Follow this and additional works at: https://knowledgecommons.popcouncil.org/departments_sbsr-pgy How does access to this work benefit you? Let us know!

\section{Recommended Citation}

"Selected DHS data on 10-14-year-olds: Côte d'Ivoire," annex to "Facts about adolescents from the Demographic and Health Survey: Statistical tables for program planning." New York: Population Council, 2003. 


\section{Seleated DiB Data on 10-14-year-ollis / Gỗte dillvoire}

\section{Preface}

Several years ago the Population Council produced special tabulations for 47 countries that provided a broad map of the living circumstances, schooling, marital status, reproductive health knowledge and behavior, and work experiences of adolescent boys and girls 10-19 years old. These tables drew on three Demographic and Health Survey sources: the household survey, the survey of girls and women of reproductive age, and, where available, parallel studies of boys and men of reproductive age. In these reports (entitled "Facts About Adolescents from the Demographic and Health Survey"), data on 10-14- year-olds are arrayed alongside data on 15-19-year-olds, which we believe is the ideal presentation of such data.

More recently, there has been a demand by program and policy audiences to separate out the relatively scarce data which exists on 10-14-year-olds from the 15-19-year-old cohort in an effort to make them user-friendly for program planning exercises. We have responded to this request by preparing separate data sheets which include the variables of the original tables in addition to several new ones. For example, special effort has been expended to explore the presence of 10-14year-olds in potentially protective structures - families and schools - by cross-tabulating the presence of 10-14-year-olds in different kinds of living arrangements with school enrollment.

While early adolescence, for many, may be marked by relative good health and stable family circumstances, it can also be a period of vulnerability and intense transition. 10-14-year-olds progress from being clearly "children" at age 10, through the onset of puberty, to being perceived in some societies - in the case of girls - as "young women" ready for sexual relations, marriage, and childbearing, and — in the case of boys - as "young men" ready to help support their families and even serve in the military. Young adolescents are more likely than older adolescents to be in residence with parents and in school; however, their absence from school or lack of parental support (e.g., a surprisingly high proportion of 10-14-year-olds live with one or neither parent in many parts of sub-Saharan Africa) may be cause for concern. While some of these young people not residing with parents may be with their extended family, or in positive fostering or protective living arrangements, it is plausible that many are vulnerable to sexual exploitation, unsafe work, and substance abuse.

A new generation of research and interventions directed at the 10-14-year-old age group is urgently needed. Diagnostic work must define the key transitions and specify capacities, risks, and opportunities by age, gender, schooling, and marital status at the very least. The five-year cohort of 10-14-year-olds homogenizes too much of early adolescence and its rapid transitions. As research progresses, a more detailed picture of thresholds of change will emerge - it is possible that the fortunes of adolescents are determined not in five-year blocks, but rather in six-month, one-year, or three-year blocks, depending on the context. Collecting reliable data on young adolescents, 
either from them or from intermediaries, is a considerable challenge. Some question the quality of data collected directly from very young adolescents, preferring to rely on retrospective reporting from older age cohorts. Moreover, there are important ethical considerations surrounding consent and parental permission to interview young people. Although we recognize and acknowledge these dilemmas, we contend that new data-gathering approaches, tools, and methodologies are warranted.

We must include questions concerning the social significance of puberty and how it shapes the ways in which young boys and girls think about themselves and how they are perceived by families and communities. Young people's perceptions and experience of their sexuality and gender roles are also key subjects to explore. Finally, we must include questions surrounding marriage, as a decreasing but significant proportion of girls in some regions are married or are altering important life patterns schooling, types of work, mobility - on the premise that they will marry by age 18. An early transition to marriage may make girls particularly vulnerable in settings where the HIV epidemic is underway and spousal age difference is high. We must learn more about the marriage process, including mate selection, extent of young people's input, timing considerations, and the engagement period. Critical gaps remain in our knowledge of sexual consummation and expectations within early marriage, and the social and health impact of marriage on young people, particularly girls.'

The good news is that because of their age, young adolescents, even those in precarious circumstances, are resilient and flexible. Much can be done to remedy their situations before the architecture of their later life becomes set. Some of the young people we are most concerned about those without parental support and not in school - may need to have their living situations stabilized before schooling, livelihoods or health interventions will be effective. To this end, creating safe spaces such as girls' clubs, boys' clubs, and hostels for street children may prove to be a lifeline.

In reviewing these data on very young adolescents, what we mainly know is that we don't know very much. We urge caution in attributing more significance to these data than is warranted at this time and believe they are best understood in comparison to other age cohorts. Overall, we believe that efforts to supplement the DHS with other data sources are needed to get a broader picture of the lives of 10-14-year-olds. We hope that researchers will foster a new wave of quantitative and qualitative inquiry into the lives of this age group. And we further hope that their partners - policymakers and service providers - will draw on this information to develop a new generation of programs designed to protect and support adolescents, assisting them in making a safe and successful transition to adulthood.

Martha Brady, Judith Bruce, Erica Chong

\footnotetext{
${ }^{1}$ The forthcoming National Academy of Sciences panel report on the transition to adulthood in developing countries explores many of these issues with cross-cultural data; it will be available from the Academy by the end of 2003. Currently available is an article on some of the marital dimensions of interest by Barbara Mensch, Susheela Singh, and John Casterline entitled "Trends in the timing of first marriage among men and women in the developing world." (This paper was presented at the Population Association of America's May 2003 meeting in Minneapolis.)
} 
1. Urban-rural residence and population distribution

\begin{tabular}{|lccc|c|}
\hline & \multicolumn{3}{c}{ Percent distribution } & \\
\cline { 2 - 3 } & Urban & Rural & Total & $\begin{array}{c}\text { Age group as percent of } \\
\text { total population }\end{array}$ \\
Girls & 40.3 & 59.7 & 100.0 & 7.0 \\
Boys & 30.7 & 69.3 & 100.0 & 7.0 \\
\hline
\end{tabular}

- The majority of adolescents 10-14 years old live in rural areas. Girls are more likely than boys to live in urban areas.

- 10-14-year-olds comprise $14 \%$ of the country's total population.

\section{Parental survival status}

- Approximately nine out of ten young adolescents have both parents living.
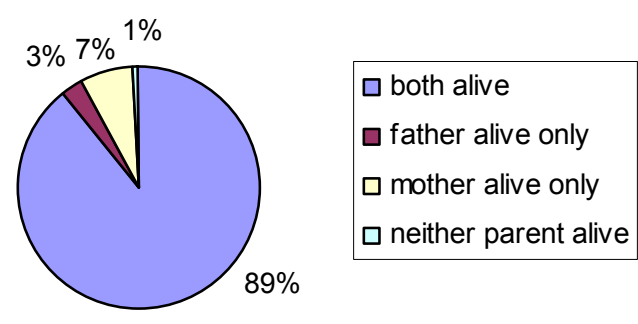

\section{Parents resident in household (hh) by place of residence and sex}

- Less than half of adolescents 10-14 years old live with both parents.

- Roughly one-third of girls and one-fourth of boys live in households with neither parent.

- Forty-one percent of 10-14-year-old urban girls do not live with either parent.

Urban girls

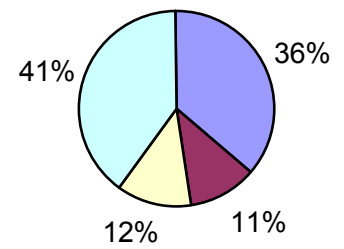

Urban boys

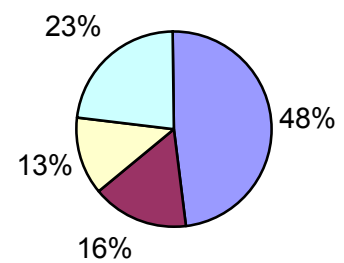

Rural girls

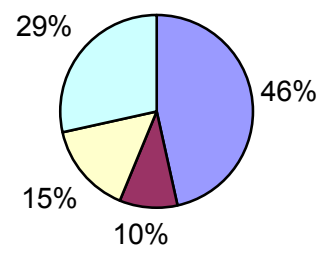

Rural boys

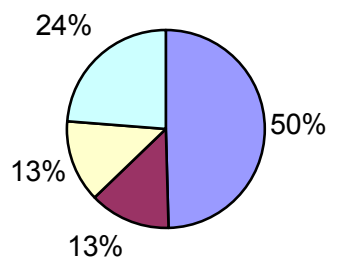

$\square$ both parents in hh

ather only in hh

$\square$ mother only in hh

$\square \quad$ neither parent in hh 


\section{0-14-year-olds}

\section{Characteristics of household head}

Note that if an adolescent has a female household head, there may or may not be an adult male present in the household.

- More than one-eighth of young adolescents live in female-headed households.

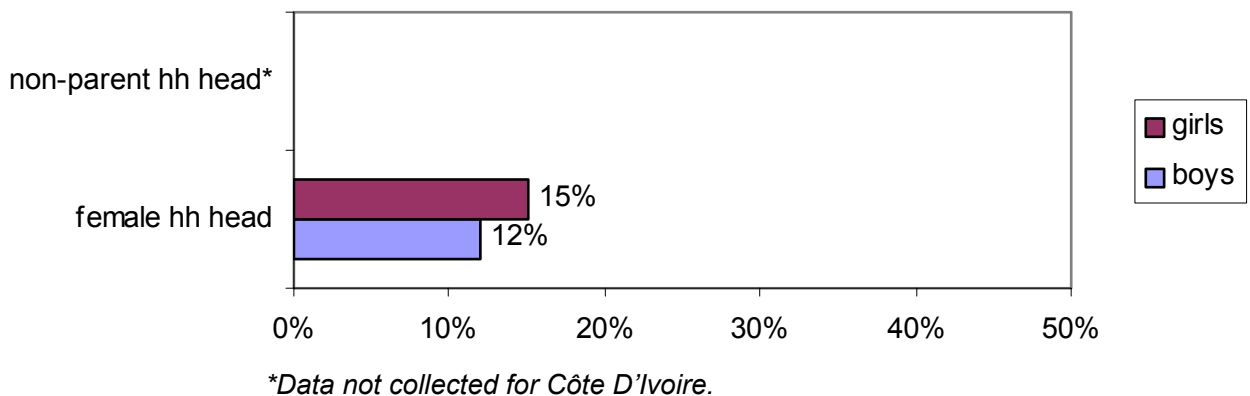

\section{Educational enrollment}

- More than one-half of girls and one-third of boys are not enrolled in school.

- Urban adolescents are more likely than rural adolescents to be in school.

- A greater percentage of boys are in school compared to girls.

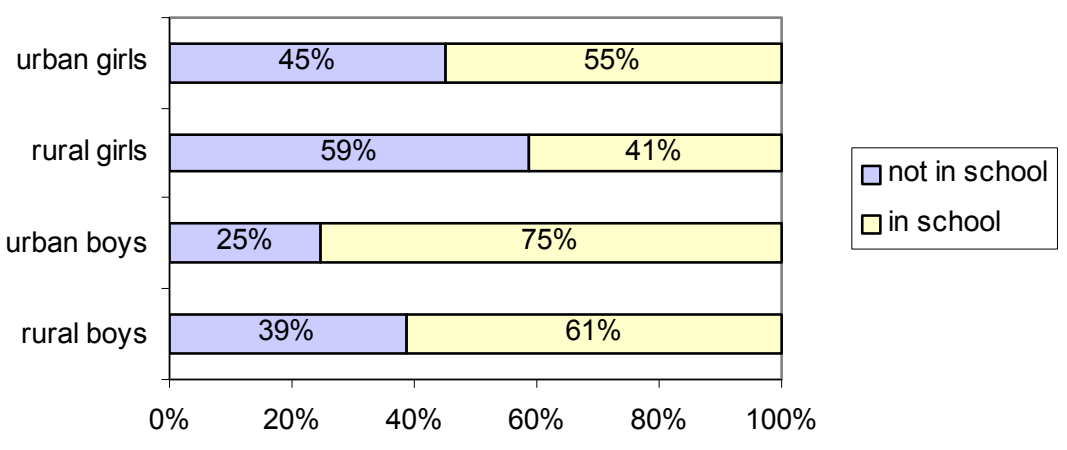

6. Distribution of girls and boys by living arrangements and school enrollment (percent)

\begin{tabular}{|lcccccc|}
\hline Living arrangements & $\begin{array}{c}\text { Not in } \\
\text { school }\end{array}$ & $\begin{array}{c}\frac{\text { Girls }}{\text { In school }} \\
\text { Both parents in hh }\end{array}$ & \% of total & $\begin{array}{c}\text { Not in } \\
\text { school }\end{array}$ & $\begin{array}{c}\text { Boys } \\
\text { In school }\end{array}$ & \% of total \\
Father only in hh & 22.0 & 20.1 & $\mathbf{4 2 . 1}$ & 19.5 & 29.6 & $\mathbf{4 9 . 1}$ \\
Mother only in hh & 4.0 & 6.3 & $\mathbf{1 0 . 3}$ & 4.0 & 10.0 & $\mathbf{1 4 . 0}$ \\
Neither parent in hh & 7.2 & 6.9 & $\mathbf{1 4 . 1}$ & 4.7 & 8.6 & $\mathbf{1 3 . 3}$ \\
Total & 22.9 & 10.7 & $\mathbf{3 3 . 6}$ & 10.7 & 12.9 & $\mathbf{2 3 . 6}$ \\
\hline
\end{tabular}

This table maps the distribution of girls and boys by living arrangement and school enrollment, calculating what percentage of all girls or all boys each subgroup comprises.

- Roughly one-fourth of boys and girls are living with both parents and are enrolled in school.

- Girls living with neither parent who are not in school make up $23 \%$ of all girls 10-14 years old. 


\section{Girls and boys not enrolled in school, by living arrangements (percent not enrolled)}

- Adolescents 10-14 living with only their father are the most likely to be in school; those living with neither parent are the least likely.

- $\quad$ Sixty-eight percent of girls compared to $45 \%$ of boys living with neither parent are not in school.

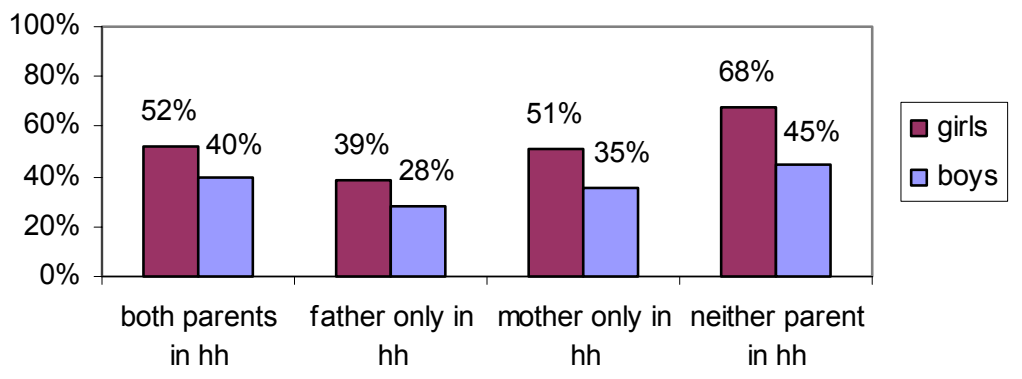

8. Girls' retrospective reporting of age at first intercourse, marriage, and first birth

\begin{tabular}{|c|c|c|c|c|}
\hline \multirow[t]{2}{*}{ Age group } & \multicolumn{2}{|c|}{$\begin{array}{c}\% \text { who had intercourse } \\
\text { before age } 15\end{array}$} & \multirow[t]{2}{*}{$\begin{array}{l}\% \text { who married } \\
\text { before age } 15\end{array}$} & \multirow[t]{2}{*}{$\begin{array}{c}\% \text { who gave birth } \\
\text { before age } 15\end{array}$} \\
\hline & Premarital & Marital & & \\
\hline $15-19$ & 16.6 & 5.6 & 7.5 & 5.8 \\
\hline $20-24$ & 17.3 & 7.3 & 9.5 & 7.6 \\
\hline $25-29$ & 16.8 & 9.5 & 12.6 & 8.2 \\
\hline
\end{tabular}

- Over one-fifth of 15-19-year-old girls reported having intercourse by their 15th birthday.

- The majority of sexual activity in early adolescence is premarital.

- There appears to have been a decline in the percentage of girls getting married before age 15.

\section{Media exposure, as measured by household ownership}

- $\quad$ Thirty-eight percent of young adolescents live in a household that has a television, and $72 \%$ live in a household that has a radio.

- Urban adolescents are more than three times as likely as rural adolescents to live in a household that has a television.

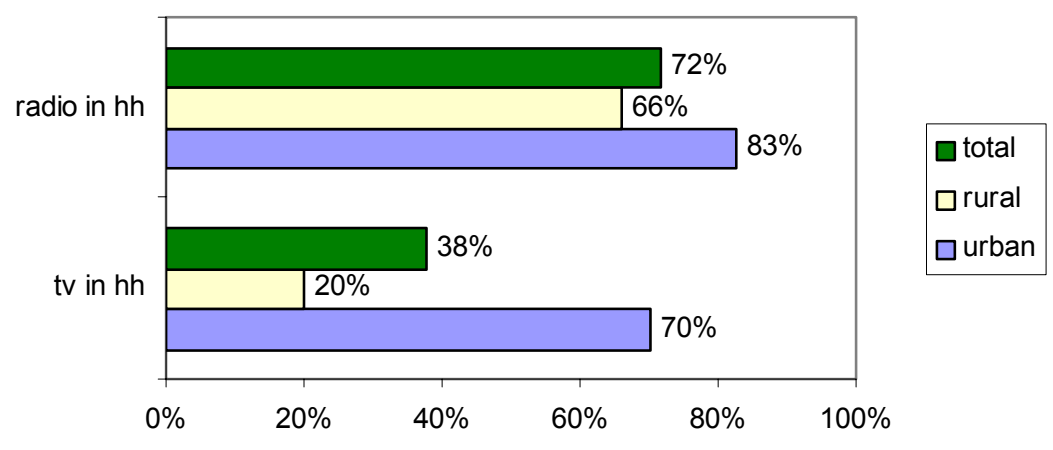

Technical notes: Tables 1, 4, 5, 8 and 9 are calculated from data collected for the 1998-1999 Côte d'Ivoire Demographic and Health Survey (DHS), conducted by the Institut National de la Statistique and Macro International, Inc. A nationally representative sample of 2,122 households was surveyed. Data was collected on 958 boys and 955 girls between ages 10 and 14. The information presented in Tables 2, 3,6 and 7 was excerpted from the 1994 Cote d'Ivoire DHS, as this information was not collected for the 1998-1999 survey. The 1994 DHS surveyed a nationally representative sample of 5,935 households, including 2,511 boys and 2,560 girls. The calculations for Table 8 are based on an individual questionnaire that was applied to 15-19-year-olds ( $N=775), 20-24$-year-olds ( $N=577)$, and 25-29-year-olds ( $N=501)$. 